\title{
CHROMOSOMAL CHARACTERS OF THE INDONESIAN SAND GOBY, OXYELEOTRISMARMORATA BLKR. 1874 (ELEOTRIDAE)*)
}

\author{
JMMYT. MASAGCA \\ Catanduanes State Colleges \\ College of Agriculture and Fisheries, Virac, \\ Catanduanes 4800, Philippines \\ and \\ KOMAR SUMANTADINATA \\ Faculty of Fisheries, Bogor Agricultural University, \\ Darmaga Campus, Bogor, Indonesia
}

\begin{abstract}
Karyomorphological investigation of sand goby or marble sleeper (Oxyeleotris marmorata Blkr.) from Cirata Reservoir, West Java, Indonesia was undertaken to determine the modal chromosome number and fundamental number, and to construct the karyotype from somatic metaphase cells of head kidney. A total of 30 fish samples from Cirata Reservoir was sacrificed for direct chromosome preparation by colchicine-citrate-aceto-methanol-Giemsa staining-air drying technique. Chromosome set analysis showed that the modal chromosome number of the test fish is $2 n=46$, confirming previous studies. Fundamental number is 50 . Two karyotypic formulas were found, i.e. 1) $2 n=46(4 S M+42 A)$; and 2) $2 n=46(2 M+2 S M+42 A)$.
\end{abstract}

Key Words: Freshwater fishes, Chromosome analysis, Oxyeleotris marmorata, Indonesia

\section{INTRODUCTION}

Sand goby or marble sleeper (O. marmorata Blkr.) is an important freshwater food fish in most Southeast Asian countries notably in Thailand, Indonesia and Singapore (Tan \& Lam 1973; Tavarutmaneegul \& Lin 1988). This eleotridine gobioid is the largest in the world (Smith 1965) and found naturally in streams, rivers, lakes or reservoirs and old mining pools in Southeast Asia (Weber \& de Beaufort 1953; Noerdin \& Sidik 1979; Mohsin \& Ambak 1983). In the Philippines, this fish was collected in Laguna de Bay Lake by Meyer in 1885 but no other account has been made about its range in this country (Herre 1927).

O. marmorata (locally known in Indonesia as "Ikan betutu") has been the focus of significant research because of the increasing market demand as an export

*) Part of a Long-Term Research Fellowship work undertaken at SEAMEO BIOTROP in 1991. 
commodity to Singapore, Hongkong and Taiwan. It has been cultured in Thailand (Supamataya 1988), Vietnam (Pantulu 1976) and other countries in Southeast Asia since the 1970's because of its suitability for aquaculture. It has wide tolerance to $\mathrm{pH}$ (Lie 1968) and can survive at low oxygen tensions. It has a high reproductive rate and is a multiple spawner (Tavarutmaneegul \& Lin 1988). It was introduced in Saguling Reservoir of West Java, Indonesia in 1986 (Munro et al. 1990) and has spread to the adjacent reservoir of Cirata.

The commercial value of sand goby is increasingly recognized in many parts of Southeast Asia, but very little is known about its basic genetics. Extensive literature search only identified the studies of Arai and Fujiki (1979) and Manna (1989) on the chromosomal complement of sand goby and both needed further investigation. These studies utilized the gill epithelial cells as the source of chromosomes, while the present study used the kidney.

This study reports on the results of karyological investigation of sand goby obtained from a population in Cirata Reservoir, Bogor, Indonesia. Specifically, this study provides information on the somatic chromosome number, fundamental number or number of chromosome arms and the karyotypic formula.

\section{MATERIALS AND METHODS}

Live samples of sand goby were obtained from Cirata Reservoir in Cianjur, Bogor, West Java and were temporarily stored at the indoor tanks of SEAMEO BIOTROP laboratories. The fish specimens were identified based on the taxonomic descriptions of Mohsin \& Ambak (1983). The methodology of chromosome preparation followed that of Rivlin et al. (1985) and Reddy \& John (1987), with very minor modifications. Six hours prior to sacrifice, the test fish was intramuscularly injected with $0.05 \%$ colchicine in $0.9 \% \mathrm{NaCl}$ at a dose of $1 \mathrm{ml} / 100 \mathrm{~g}$ body weight. The chromosomes were prepared directly using head kidney tissue. Hypotonization was done using $0.5 \%$ sodium citrate at a duration of 30 to $40 \mathrm{~min}$. and at room temperature of 25.5 to $26.5^{\circ} \mathrm{C}$. Prepared slides were conventionally stained with $4 \%$ Giemsa at a $\mathrm{pH}$ of 6.5 . The different chromosomes were designated as proposed by Levan et al. (1964).

\section{RESULTS}

From 303 metaphase kidney cells of 30 pre-adult sand goby samples collected from Cirata Reservoir it revealed that the modal chromosome number (MCN) of 
this eleotridine goby is 46 . Chromosome counts varied from 38 to 50 . Out of the 303 metaphase cells analyzed, 117 cells $(38.61 \%)$ have the characteristic count of $2 n=46 ; 44$ cells $(14.52 \%)$ have $2 \mathrm{n}=44 ; 36$ cells $(11.88 \%)$ have $2 \mathrm{n}=43 ; 24$ cells $(7.92 \%)$ have $2 \mathrm{n}=$ $42 ; 14$ cells $(4.62 \%)$ have $2 n=41 ; 10$ cells $(3.30 \%)$ have $2 n=40$ and 2 cells $(0.66 \%)$ have each $2 n=39$ and $2 n=38$ (Fig. 1).

Figure 1. Frequency distribution of diploid chromosome counts of marble sleeper collected from Cirata Reservoir

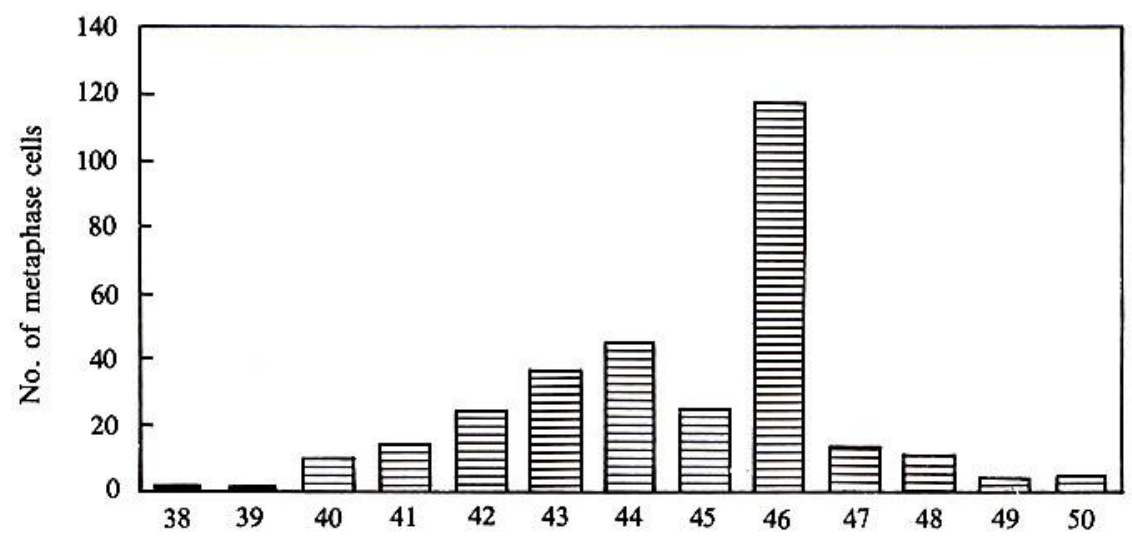

No. of chromosomes

Total no. of metaphase cells analyzed: 303

Eighteen $(60 \%)$ out of the 30 fish samples analyzed showed a modal chromosome number $(\mathrm{MCN}) 2 \mathrm{n}=46 ; 4$ samples $(13.3 \%)$ have $\mathrm{MCN} 2 \mathrm{n}=44 ; 3$ samples $(10 \%)$ have $2 n-42$; and only 2 samples $(6.66 \%)$ have each $2 n=41$ and $2 n=40$.

Karyotypes were made based on mitotic figures in which the chromosomes were clearly recognizable. The homologous chromosome pairs were identified based on the procedures of Levan et al. (1964). The chromosome set of this fish mostly consists of 2 pairs of bi-armed and 21 pairs of mono-armed chromosomes. The karyotype showed that 2 pairs of chromosomes were sub-metacentric (SM), where the first pair was larger than the second one. The test of chromosome pairs showed all acrocentrics (A). In some cells the second pair seems to have a metacentric (M) chromosome, but this was not constant. Another karyotypic formula was also found in this study having $2 \mathrm{n}=46(2 \mathrm{M}+2 \mathrm{SM}+$ 42A). 


\section{DISCUSSION}

Previous data on the diploid chromosome number of $O$. marmorata analyzed from fish samples obtained in Thailand (Arai \& Fujiki 1979) and from India (Manna 1989) are the same with the present investigation. A diploid number of $2 n=46$ and fundamental number (NF) of 50 confirm their previous findings. The diploid number of 46 recorded in sand goby has also been recorded in' another species of the same genus, $O$. acanthopomus $(2 n=46)$ from Japan (Arai \& Sawada 1974). The same diploid number was also recorded in other gobioid species, Dormitator maculatus from Mexico (del Carmen-Maldonado et al. 1985), Boleophtalmuspectinorostris and Periophthalmus cantonensis (Nogusa 1960, cited by Denton 1973). However, D. maculatus has a fundamental number of 90 , which is higher than $O$. marmorata having an $\mathrm{NF}=50$. In the Gobiidae, most of the genera have the diploid chromosome number of $2 n=44$ to $2 n=48$ as shown in Bathygobius fuscus $(2 n=48)$, Glossogobius giurus $(2 \mathrm{n}=46)$ and Chaetogobius annularis $(2 \mathrm{n}=44)$.

Based on cytological examination variable counts of 42, 43, 44 and 46 were also known in this study. This could be due to the technical limitations. The suggestion that possible chromosonal re-arrangement by Robertsonian translocations may have occurred was discounted since the missing chromosomes in the metaphase spreads are different from each other and cannot be considered as inherent property of the test fish.

Some metaphase spreads have a small metacentric chromosome, but it was not constant in the cells analyzed. The earlier work of Arai \& Fujiki (1979) reported two formulas: 1) $2 \mathrm{n}=46(2 \mathrm{M}+2 \mathrm{SM}+42 \mathrm{ST}, \mathrm{A})$ and 2$) 2 \mathrm{n}=46(1 \mathrm{M}+3 \mathrm{SM}+42 \mathrm{ST}, \mathrm{A})$. Although a metacentric chromosome was seen in few spreads, majority of the 303 cells analyzed have 2 pairs of sub-metacentric chromosomes. This study reports a new karyotypic formula of sand goby as $2 n=46(4 \mathrm{SM}+42 \mathrm{~A})$. After careful examination of the chromosome set, it seems that no heteromorphic pairs could be referred to as sex chromosomes.

\section{ACKNOWLEDGEMENT}

The author is grateful for the long-term fellowship granted by SEAMEO BIOTROP and the permission of the Catanduanes State Colleges in Virac, Catanduanes, Philippines for allowing the author to travel to Indonesia while on a PASUC scholarship at De La Salle University. This study is a part of the Masteral Thesis submitted to DLSU Graduate Biology Department in Manila. Profound thanks are due to Dr. Ruben C. Umaly (the initial supervisor of this research), Dr. Soekotjo 
Chromosomal characters of the Indonesian - Jimmy T. Masagca and Komar Sumantadinata

(SEAMEO BIOTROP Director) and Dr. Sutrisno Sukimin (TAB Programme Manager). Special thanks are due to Mr. A.B. Djunaedi, Mr. Widodo, Ms. Wati and other staff of BIOTROP for the assistance provided. The assistance of Mr. Harton of IPB is greatly appreciated.

\section{REFERENCES}

ARAI, R. and A. FUJKI. 1979. Chromosomes of Japanese gobioid fishes (IV). Bull. Natl. Sci. Mus. Ser.

A, 5(2): 153-159.

ARAI, R. and Y. SAWADA. 1974. Chromosomes of Japanese gobioid fishes (I). Bull. Natl. Sci. Mus.

Tokyo, 17: 97-102.

DELCARMEN-MALDONADO,M., M. URIBE-ABROCER,J. ARREOUIN-ESPINOSAand A. CASTRO-PEREZ

1985. Karyotypical studies on Dormitator maculatus Bloch and Gobiomorus dormitatur Lacepede

(Gobioidei: Perciformes). Cytologia, 50(4): 663-667.

DENTON, T.E. 1973. Fish chromosomes methodology. Charles C. Thomas Publisher, Springfield, Illinois.

HERRE, A. 1927. Gobies of the Philippines. Monog. 23 Bur. Sci. Manila.

LEVAN, A., K. FREDGA and A. SANDBERG. 1964. Nomenclature for centromeric position on chromosomes. Hereditas, 52: 201.

LIE, S.F. 1968. A study of some biological aspects of $O$. marmorata found in Singapore. Part 2. Dept. of Zoology, Univ. of Singapore. $26 \mathrm{p}$.

MANNA, O.K. 1989. Fish cytogenetics related to taxonomy, evolution and monitoring genotoxic agent. p. 21-46. In: Das and Jhingran (eds). Fish Genetics in India. Today and Tomorrows Printers and Publishers, New Delhi.

MOHSIN, M.A.K. and M.A. AMBAK. 1983. Freshwater fishes of Peninsular Malaysia. Penerbit Universiti Pertanian, Malaysia, Kuala Lumpur.

MUNRO, J., ISKANDAR and B.A. COSTA PIERCE. 1990. Fisheries of the Saguling Reservoir and a preliminary appraisal of management options, p: 285-328. In: B.A. Costa Pierce and O. Soemarwoto (eds.). Reservoir fisheries and aquaculture development for resettlement in Indonesia. ICLARM Tech. Rep. 23.

NOERDIN, N. and A. SIDIK. 1979. Survei ikan bakut (O. marmorata Blkr.) di Danau Jempang dan Semanikarya. Dinas Perikanan Propinsi Dati I Kalimantan Timur. (In Indonesian).

PANTULU, V.R. 1976. Floating cage culture of fish in the Lower Mekong Basin, p. 416-423. In: T.V.R. Pillay and W.A. Dill (eds.). Advances in aquaculture. FAO Tech. Conf. on Aquaculture. Fishing News Int.

REDPY, P.V.G.K. and G. JOHN. 1987. A method to increase mitotic metaphase spreads in permanent chiomosome preparations for karyotype studies of fishes, p. 199-205. In: Proceedings of World Symposium on Selection, Hybridization and Genetic Engineering in Aquaculture, Berlin, 27 - 30 May 1986.

RIVLIN, K., J.W. RACHLIN and G. DALE. 1985. A simple method for the preparation of fish chromosomes applicable to fieldwork, teaching and banding. J. Fish Biol., 26: 267-272. 


\section{BIOTROPIA No. 7, 1994}

SMITH, H.M. 1965. The freshwater fishes of Siam or Thailand. Tropical Fish Hobbyists Publication, Inc. USA.

SUPAMATAYA, M. 1988. The study of disease in sand goby (Oxyeleotris marmoratus Bleeker) in cage culture and some environmental factors related to infection. M.S. Thesis. Kasetsart University, Thailand.

TAN, O. and T.J. LAM. 1973. Induced breeding and early development of the marble goby (Oxyeleotris marmorata). Aquaculture, 2: 411-423.

TAVARUTMANEEOUL, P. and C.K. LN. 1988. Breeding and rearing of sand goby (Oxyeleotris marmorata) fry. Aquaculture, 69(3/4): 299 - 306.

WEBER, M. and L.F. BEAUFORT. 1953. The fishes of the Indo-Australian archipelago. Vol. X. E. J. Brill Ltd., Leiden. 